\title{
5.2 Інновації фармацевтичної освіти: електронні ресурси для вивчення аналітичної хімії
}

В умовах сучасної фармацевтичної освіти, яка передбачає змішану форму навчання, актуальним питанням постає впровадження сучасних електронних ресурсів як додаткової інтерактивної складової навчального процесу і стимуляції майбутніх фармацевтів до пізнавальної активності на заняттях з аналітичної хімії.

Метою статті є деталізований опис зручних електронних ресурсів для вивчення аналітичної хімії, що передбачають інтерактивну складову навчального контенту дисципліни.

Грунтуючись на детальному аналізі наукових робіт Л. М. Унгурян, М. Т. Тукало, Г. В. Чернецька, І. А. Науменко, І. С. Назарко та ін. підтверджено ефективність використання електронних навчальних ресурсів для вивчення курсу навчальної дисципліни «Аналітична хімія».

Українські науковці Л. М. Унгурян, Г. В. Чернецька, І. А. Науменко засвідчують, що «інформаційні процеси стають однією 3 найважливіших складових життедіяльності людини, тому на етапі розвитку освіти стала актуальною проблема пошуку нових форм організації навчального процесу. Сучасна система вищої освіти переживає великі зміни, що приводять до вдосконалення і появи нових освітніх технологій. Сьогоднішні вищі навчальні заклади повинні активно позиціонувати свій внесок в інноваційний процес, соціальний розвиток і розробляти інноваційні технології, які забезпечать формування професійних умінь у студентів. Вданий час зростає кількість інформації, яка так необхідна для отримання, розуміння і засвоєння рівнів освіти»[367].

Вчена О. М. Науменко впевнена, що «інформаційні технології дозволяють будувати відкриту систему освіти, корінним чином змінювати організацію процесу навчання, раціонально організовувати пізнавальну діяльність, формуючи в учнів навички системного мислення. За прогнозними оцінками фахівців, освіта on-line буде поступово витісняти традиційну систему освіти, оскільки використання комп’ютерів і відповідних електронних засобів 
навчального призначення дозволяє індивідуалізувати навчальний процес на основі принципово нових пізнавальних ресурсів»[368].

Як засвідчує вітчизняна дослідниця М. Т. Тукало «згідно Положення «Про електронні освітні ресурси» електронні освітні ресурси є складовою частиною навчально-виховного процесу, мають навчально-методичне призначення та використовуються для забезпечення навчальної діяльності і вважаються одним 3 головних елементів інформаційно-освітнього середовища, що є важливим для навчального хімічного експерименту, який одночасно $є$ і способом здобування знань і видом практичної діяльності, що підтверджує їх істинність. Демонстраційний експеримент $\epsilon$ експериментальним методом, що застосовується в науці для розкриття закономірності зв'язків і взаємодії між речовинами та вивчення сутності хімічних процесів і умов їх протікання. Інформаційне середовище навчання хімії, що реалізується на засадах інтеграції спеціалізованих програмно-інструментальних засобів і освітнього контенту, $є$ основою відносин та інтерактивного спілкування суб'єктів освітнього процесу викладачів i здобувачів. Інформаційне середовище $\epsilon$ практичним інструментарієм підготовки i проведення занять, створення електронних навчальних матеріалів із забезпеченням доступу здобувачів до мережних освітніх ресурсів. Відповідно до концепції інноваційних технологій навчання освітне середовище 3 хімії складається 3 матеріально-ресурсного та інформаційного компонентів. До матеріально-ресурсного відносяться аудіовізуальні засоби (мультимедійні проектори, інтерактивні електронні дошки, планшети, рідери тощо), що забезпечують зорову інформацію, яка в процесі навчання може виконувати різноманітні функції: служити візуальною опорою для розуміння сутності хімічних процесів, проектувати на екран різні ситуації, виконувати функцію зворотного зв'язку» [369].

Дослідниця Ю. Момот підкреслює, що «хімія як наука часто оперує уявними поняттями (атом, молекула, електронна конфігурація, хімічна реакція та інше), що ускладнює іiі сприйняття. Сутність багатьох хімічних процесів та об'єктів не може бути показана наочно інакше, як шляхом демонстрації певних 
моделей. Часто студенти приходять на навчання у заклади освіти уже зі сформованою «хемофобією», тобто з уявленням того, що хімія - це складна наука, i, навіть, відсутністю бажання її опанувати. І у цьому випадку важливим $\epsilon$ використання можливостей комп’ютера як засобу наочності для демонстрації різних об’єктів пізнання хімічної науки, що реалізується шляхом включення до дистанційного курсу ілюстрацій та відео фрагментів»[370].

Таку ж думку поділяють науковці О. М. Антипенко, В. В. Ставицький, О. Ю. Воскобойнік, С. І. Коваленко, що зазначають, «ефективність викладання хімічних дисциплін значною мірою залежить від якості візуалізації навчального матеріалу. Враховуючи зазначене доцільним $\epsilon$ використання в якості допоміжного програмного забезпечення редакторів хімічних формул та додатків, що дозволяють створювати тривимірні моделі молекул хімічних сполук. Необхідно зазначити, що незважаючи на те, що найбільш функціональне програмне забезпечення даної категорії $є$ комерційним, існують і вільні або безкоштовні для використання в академічних цілях представники. Так, викладачами з успіхом використовувались хімічні редактори BKChem (Beda Kosata, відкрите програмне забезпечення) та ChemSketch (Advanced Chemistry Development Inc., безкоштовне для використання в академічних цілях), KingDraw (безкоштовний редактор хімічних структур, доступний на Android, iOS та Windows PC) та програмний засіб молекулярного моделювання Avogadro. Зазначене програмне забезпечення інтегрувалось з MS Teams через функцію «поділитись вмістом», яка дозволяє демонструвати учасникам відеоконференції робоче вікно визначеної програми. 3 усіх додаткових програмних засобів найбільш корисним виявився саме додаток Avogadro, адже демонстрація студентам моделей дозволяє значно полегшити пояснення такого матеріалу як конформерія, геометрична та оптична ізомерія, вплив просторової будови органічних сполук на їх реакційну здатність та механізми хімічних перетворень. Викладачі мотивували студентів до використання зазначених онлайн сервісів, що надають доступ про інформації про будову та реакційну здатність органічних сполук (www.pubchem.ncbi.nlm.nih.gov, www.orgsyn.org тощо)»[371]. 
Впровадження електронних ресурсів для вивчення хімічних дисциплін, як зазначає науковець I. С. Назарко, значно підсилює наступні показники: «професійна спрямованість (акцент на завдання майбутньої професійної діяльності); інтерактивність (вербальний чи невербальний діалог між людиною та комп'ютером); гнучкість (зручний час, місце, темп роботи); мобільність (ефективний зворотній зв'язок між викладачем та студентом); індивідуалізація (індивідуальний підхід); співробітництво і співтворчість; масовість (доступність необмеженої кількості студентів до багатьох джерел інформації); технологічність (використання нових досягнень у галузі інформаційних технологій); новий статус викладача (як координатора навчального процесу, консультанта, керівника навчальних проектів)»[372].

Характерними рисами електронних навчальних ресурсів, як зазначають дослідники Л. М. Унгурян, Г. В. Чернецька, І. А. Науменко є: «гнучкість: студенти не відвідують регулярних занять у вигляді лекцій і семінарів, а працюють у зручний для себе час у зручному місці; модульність: в основу освіти кладеться модульний принцип. Кожний окремий курс створює цілісне уявлення про певну галузь знань; економічна ефективність: досвід вітчизняних недержавних центрів показує, що їх витрати складають приблизно 60 \% витрат на підготовку фахівців за денною формою; нова роль викладача: на нього покладаються такі функції, як координування пізнавального процесу, коректування курсу, що викладається, консультування при складанні індивідуального навчального плану та ін.; спеціалізовані форми контролю: в якості форм контролю використовуються дистанційно-організовані співбесіди, практичні і курсові роботи; використання спеціалізованих технологій: сукупність методів, форм і засобів взаємодії в процесі самостійного, але контрольованого освоєння певного об'єму знань»[373].

Створення власного навчального контенту дисципліни «Аналітична хімія» передбачає врахування вимог академічної доброчесності, що, з дослідження вітчизняних науковців Н. Нагорна, П. Гуща поєднує «етичні норми і правові засади в науці, яких повинні дотримуватися педагогічні, науково-педагогічні й 
науково-технічні працівники, здобувачі освіти та заклади вищої освіти на всіх рівнях системи освіти з метою забезпечення якості науки й освіти та довіри до них»[374].

Навчальний контент дисципліни «Аналітична хімія» має включати: повний комплект лекційного матеріалу курсу, навчений матеріал лабораторних та практичних робіт, індивідуальні проектні роботи здобувачів освіти, а також самостійну роботу студентів.

Для повноти охоплення матеріалу курсу слід застосовувати відео-лекції та відео лабораторних робіт, які включають відеофільми технологічних, лабораторних, хімічних та інших процесів 3 обов'язковим коментуванням правильності виконання викладачем. Головним кроком впровадження сучасних електронних ресурсів для додаткової інтерактивної складової навчального процесу є завантаження власного навчального контенту дисципліни «Аналітична хімія» до основного серверу Microsoft Office 365 (Microsoft Teams, OneDrive, Microsoft Stream, OneNote, Class Notebook, Office Mix, Microsoft Movie Maker, Microsoft Forms, Microsoft Sway). Навчальна платформа Microsoft Teams дає змогу залучати здобувачів фармацевтичної освіти до командної роботи (спілкування в командах, перемови по кімнатам з метою виконання проектної роботи, групова робота доповідачів в режимі реального часу); командна робота в BreakOut Rooms. Велику роль у підтриманні зацікавленості майбутніх фармацевтів до вивчення аналітичної хімії є створення атмосфери викладання в умовах дистанційної освіти, а саме: фону зображення доповідача та організатора 3 врахуванням специфіки викладання хімічної дисциплін (налаштування фонових фільтрів - лабораторії 3 контролю якості лікарських засобів та лабораторії фармацевтичного аналізу).

Окремі завдання та хімічні задачі можна оформити як додаткові інтерактивні матеріали навчального курсу на непровідному сервері, що забезпечується додаванням додаткових вкладок (додаткових серверів, що забезпечують інтерактивність викладання дисципліни: електронні дошки, 
електронні книги, стрічки часу, інтелект-карти, інфографіка тощо) у Microsoft Teams.

В результатів деталізованого огляду навчальних ресурсів, що застосовуються у фармацевтичній освіті, було розроблено комплект рекомендованих додаткових вкладок, а саме: електронні дошки (мережевий соціальний ресурс, призначений для організації спільної роботи зі створення й редагування зображень і документів, спілкування в реальному часі, в курсі аналітичної хімії дають змогу розмістити алгоритми проведення титриметричного аналізу, хімічні перетворення методів): URL: https://www.classroomscreen.com; URL: https://www.gynzy.com/en/; URL: https://flinga.fi/tools; URL: https://trello.com; URL: https://en.linoit.com; URL: https://witeboard.com; URL: https://uk.padlet.com/dashboard; інтерактивне відео (медіа 3 передбаченою можливістю для прямого зворотного зв'язку, діалогу 3 аудиторією. Реалізуються за допомогою телефонного, відео, супутникового та інтернет-зв'язку, комп'ютерних та відеоігор. В курсі аналітичної хімії інтерактивні відео передбачають деталізоване правильне виконання лабораторних робіт повного хімічного аналізу субстанції): URL: https://h5p.org; URL: https://go.playposit.com; URL: https://edpuzzle.com; електронні книги (версія книги в електронному (цифровому) вигляді. Такі книжки можна читати за допомогою комп'ютерів, мобільних телефонів чи спеціалізованих пристроїв. Дають змогу забезпечити всіх здобувачів освіти цифровими підручниками та посібниками 3 дисципліни «Аналітична хімія»): URL: https://www.ourboox.com; https://bookcreator.com; стрічки часу (спосіб візуалізувати навчальний матеріал. Найчастіше використовується, коли маємо справу з історією або хронологією події. На заняттях аналітичної хімії дають змогу опрацювати хронологію виконання певних хімічних процесів, а також історію розвитку видів аналізу): URL: https://timeline.knightlab.com; URL: https://www.timetoast.com; URL: https:/time.graphics/ru/; інтелект-карти (звана мапа розуму, пам’яті або ж думок, що відображає слова, ідеї чи завдання. Ї̈̈ використовують для генерування, структуризації чи відображення ідей. Тема аналіз невідомої речовини з курсу 
аналітичної хімії краще опрацьовується здобувачами освіти з використанням інтелект-карт): URL: https://coggle.it; URL: https://www.mindomo.com/ru/; URL: https://www.mindmeister.com/ru; ; інфографіка (добірка зображень, діаграм i мінімального обсягу тексту, що роблять огляд теми легкозрозумілим. Максимально інформативно та доступно можна надати молекулярні та структурні хімічні формули, хімічні перетворення, ланцюги хімічних реакцій, будова міцел, схеми будови приладів тощо): URL: https:/app.genial.ly; URL: https://www.easel.ly; URL: $\quad$ https://crello.com/uk/; URL: https://www.canva.com/uk ua/stvoryty/infografika/; пазли (гра-головоломка, що виглядає як мозаїка, яку потрібно скласти з безлічі фрагментів малюнка різної форми), кросворди (гра-задача, яка полягає у вписуванні літер у перехресні рядки клітинок накресленої фігури так, щоб за горизонталлю та вертикаллю вийшли загадані слова), ребуси (загадка, в якій слова, що розгадуються, зображено у вигляді комбінації малюнків з літерами та іншими знаками). В курсі навчальної дисципліни інтерактивні електронні ресурси пазлів, кросвордів та ребусів надають змогу здобувачам освіти в ігровій формі більш легко засвоювати специфічний навчальний матеріал хімічного змісту: URL: https://www.jigsawplanet.com; URL: http://cross.highcat.org/ru_RU/\#; URL: http://rebus1.com/ua/; URL: https://puzzlecup.com/crossword-ru/.

Також рекомендовано підготувати навчальний матеріал самостійної роботи 3 навчальної дисципліни для завантаження на електронну платформу у вигляді окремого дистанційного курсу дисципліни (проект сценарію завантаження курсу, сценарій згідно з програмою, теми змістовного модулю, текстовий матеріал та графічний, пакет тестових матеріалів для контролю знань, враховуючи відкриті та закриті завдання для контролю та тренінгу).

Постійний моніторинг навчальної активності майбутніх фармацевтів через додаток Insights дає змогу вчасно виявити групи ризику серед здобувачів освіти та надати їм додаткові роз'яснення, засвоїти недостатньо опрацьований навчальний матеріал курсу «Аналітична хімія». 
TRADITIONAL MEDICINE AND PHARMACOLOGY. ACHIEVEMENTS, INNOVATIONS, AND ALTERNATIVES

Отже, впровадження сучасних електронних ресурсів як додаткової інтерактивної складової навчального процесу i стимуляції майбутніх фармацевтів до пізнавальної активності на заняттях з аналітичної хімії покращує ефективність навченого процесу. Тому, за результатам дослідження, рекомендовано використовувати можливості електронних ресурсів для вивчення аналітичної хімії, що передбачають інтерактивну складову навчального контенту дисципліни. 